\title{
Faktor Penghambat Pelaksanaan SPO 7 Benar dalam Pemberian Obat di Ruang Rawat Inap Rumah Sakit Panti Nirmala
}

\section{Factors Hindering the 7 Right SOP Implementation of Drug Delivery in Inpatient Ward Panti Nirmala Hospital}

\author{
Pratiwi Sthephani ${ }^{1}$, Aryo Dewanto ${ }^{2}$, Cecilia Widijati ${ }^{3}$ \\ ${ }^{1}$ Program studi Magister manajemen Rumah Sakit Fakultas Kedokteran Universitas Brawijaya Malang \\ ${ }^{2}$ Rumah Sakit Panti Nirmala Malang
}

\begin{abstract}
ABSTRAK
Laporan keselamatan pasien RS Panti Nirmala terdapat 34,1\% kejadian yang berhubungan terhadap kesalahan pemberian obat. Hal ini mengindikasikan pelaksanaan pemberian obat berdasarkan 7 benar belum berjalan dengan baik. Tujuan dari penelitian ini adalah untuk mengidentifikasi, menganalisis faktor penghambat pelaksanaan pemberian obat berdasarkan 7 benar sesuai standar prosedur operasional (SPO)di ruang rawat inap RS Panti Nirmala. Penelitian ini dilakukan dengan metode observasi terhadap 39 perawat pelaksana di 7 unit ruang rawat inap pada shift pagi dan sore waktu pemberian obat, baik obat oral dan intravena. Setelah melakukan observasi, peneliti memberikan kuesioner untuk mengukur pengetahuan, sikap dan kemauan perawat. Kuesioner dibagikan kepada 49 orang perawat pelaksana ruang rawat inap. Hasil observasi menunjukkan 64,9\% perawat melakukan benar pasien, 86,5\% perawat melakukan benar obat, 64,9\% perawat melakukan benar waktu, dan $100 \%$ perawat melakukan benar dosis, benar cara dan dokumentasi. Hasil kuesioner menunjukkan terdapat 89\% perawat rawat inap RSPN memiliki pengetahuan yang baik tentang prinsip 7 benar. Perawat juga memiliki sikap yang baik dalam pelaksanaan pemberian obat berdasarkan tujuh benar dan mau menjalankan prinsip tujuh benar dalam pemberian obat. Hal tersebut disebabkan kurangnya komunikasi yang efektif pada perawat terhadap pasien maupun keluarga.
\end{abstract}

Kata Kunci: 7 benar, pemberian obat, perawat

\section{ABSTRACT}

Panti Nirmala Hospital's patient safety report contained 34,1\% of events related to medication administration errors. This indicates that the implementation of drug delivery based on 7 rights is not running well. The purposes of this study are to identify and to analyze the factors inhibiting the implementation of drug delivery based on 7 rights according to the standard operating procedures (SOP) in inpatient unit of Panti Nirmala Hospital. This research was conducted by observation method towards 39 nurses in 7 units of inpatient units in the morning and afternoon shifts during drug administration, both oral and intravenous medications. After making observations, researchers gave questionnaires to measure knowledge, attitude, and willingness of nurses. The questionnaires were distributed to 49 inpatient unit nurses. The observations show $64,9 \%$ of nurses do right patients, $86,5 \%$ of nurses do right medication, $64,9 \%$ of nurses do right time, and $100 \%$ of nurses do right dose, right way and documentation. The results of the questionnaire showed that $89 \%$ of inpatient nurses have good knowledge on the principles of 7 rights. The nurses possess good attitude and have willingness in implementing drug delivery based on 7 rights. This was due to a lack of effective communication from nurses to patients and families.

Keywords: 7 rights, drug delivery, nurse,

Jurnal Kedokteran Brawijaya, Vol. 28, Suplemen No. 2, 2015; Korespondensi: Pratiwi Sthephani. Program Studi Magister Manajemen Rumah Sakit Fakultas Kedokteran Universitas Brawijaya Malang, Jl. Veteran Malang 65145 Tel. (0341) 569117 Email: ns.pratiwi_stephani@yahoo.com 


\section{PENDAHULUAN}

UU no 44 tahun tahun 2009 tentang Rumah Sakit mengamanatkan bahwa Rumah sakit harus mampu memberikan perlindungan terhadap keselamatan pasien, masyarakat, lingkungan rumah sakit, serta sumber daya manusia yang ada. Paradigma baru dalam sistem akreditasi KARS versi 2012, mengarahkan seluruh kegiatan pelayanan rumah sakit mampu memberikan pelayanan yang memenuhi standar kualitas serta jaminan rasa aman dan perlindungan terhadap dampak pelayanan yang diberikan dalam rangka pemenuhan hak-hak masyarakat akan pelayanan yang berkualitas serta aman (1).

Pada saat ini pelayanan kesehatan sangat kompleks, lebih efektif namun apabila pemberi pelayanan kurang hati-hati dapat berpotensi terjadinya kesalahan. Data di Amerika Serikat 1 diantara 200 orang menghadapi resiko kesalahan pelayanan di rumah sakit, dibandingkan dengan resiko naik pesawat terbang yang hanya 1 per 2.000 .000 maka resiko mendapatkan kesalahan pelayanan di rumah sakit lebih tinggi. Di Indonesia kasus yang paling sering terjadi adalah kesalahan obat yang tidak jarang menjadi tuntutan hukum dan berakhir di pengadilan (2).

Institute of Medicine (IOM), menyatakan bahwa paling sedikit 44.000 bahkan 98.000 pasien meninggal di rumah sakit dalam satu tahun akibat dari kesalahan medis (medical errors) yang sebetulnya bisa dicegah (2). Di Indonesia, Kejadian Tidak Diharapkan (KTD) akibat kesalahan pemberian medikasi merupakan kasus yang paling sering terjadi (2). Kuantitas ini melebihi kematian akibat kecelakaan lalu lintas, kanker payudara dan AIDS. Laporan Peta Nasional Insiden Keselamatan Pasien (Kongres Persi tahun 2007) kesalahan dalam pemberian obat menduduki peringkat pertama $(24,8 \%)$ dari 10 besar insiden yang dilaporkan (3).

Fenomena tersebut menunjukkan bahwa program keselamatan pasien rumah sakit (hospital patient safety) sangat penting dan merupakan peningkatan dari program mutu yang selama ini dilaksanakan secara konservatif (2). Saat ini upaya meningkatkan mutu pelayanan dan meningkatkan upaya keselamatan pasien dirumah sakit sudah merupakan gerakan universal. Berbagai Negara maju bahkan telah menggeser paradigma yang tidak hanya mutu tetapi juga kualitas (quality-safety). Tidak hanya mutu pelayanan yang harus ditingkatkan tetapi yang lebih penting adalah menjaga keselamatan pasien secara konsiten dan terus menerus (4).

Tujuan keselamatan pasien di rumah sakit adalah mencegah terjadinya cedera yang disebabkan oleh kesalahan akibat melaksanakan suatu tindakan atau tidak mengambil tindakan yang harusnya diambil (5). Salah satu sasarankeselamatan pasien dalam pelayanan kesehatan adalah salah satunya peningkatan keamanan obat. Studi yang dilakukan di dua rumah sakit akademik di Amerika menemukan bahwa kejadian tidak diharapkan tentang obat untuk pasien rawat inap diperkirakan 6,5 per seratus penerimaan (6). Penelitian Hug et al di rumah sakit komunitas menemukan tingkat yang lebih tinggi 15 per seratus penerimaan pasien rawat inap (7). Studi yang melibatkan 1.116 rumah sakit menemukan kejadian ini sebanyak 5,07\% dan 0,25\% di antaranya berakhir fatal (8).

Di Arab Saudi, dua studi memperkirakan prevalensi kesalahan resep obat pada rawat inap rumah sakit berkisar antara 13-56 per 100 permintaan resep. Data ini menunjukkan bahwa secar internasional keamanan obat merupakan kontributor yang penting terhadap morbiditas dan biaya kesehatan. Laporan Peta Nasional Insiden Keselamatan Pasien, kesalahan dalam pemberian obat menduduki peringkat pertama $(24,8 \%)$ dari 10 besar insiden yang dilaporkan.

Rumah Sakit Panti Nirmala telah terakreditasi penuh tingkat lengkap menggunakan sistem akreditasi 2007 dan lulus tingkat paripurna sistem akreditasi versi 2012 pada awal Januari 2013. Data insiden keselamatan pasien di Rumah Sakit pada periode bulan Januari sampai dengan Juli 2014 tercatat sebanyak 41 insiden yang terdiri dari Kejadian tidak diharapkan/KTD (9), kejadian nyaris cedera/KNC (6) serta kejadian Tidak Cedera/KTC (25). Dari 41 insiden yang dilaporkan tersebut, 14 insiden diantaranya berhubungan dengan kesalahan pemberian obat, keseluruhan insiden masuk dalam kelompok kejadian tidak cedera dan kelompok nyaris cedera (10).

Menurut Ahmadi, terdapat 3 komponen profesionalisme yaitu cognitive (pengetahuan), affective (sikap), dan psychomotor (perilaku). Oleh karena itu pengetahuan, sikap dan perilaku ini diduga dapat memepengaruhi perawat dalam melaksanakan pemberian obat berdasarkan 7 benar (9).

Tujuan dari penelitian ini untuk mengetahui gambaran umum tentang implementasi sasaran keselamatan pasien khususnya pemberian obat terkait 7 benar. Secara khusus, pengamatan ini bertujuan untuk mengevaluasi pelaksanaan pemberian obat terkait 7 benar. Mengidentifikasi faktor penghambat perawat yang berhubungan dalam melaksanakan 7 benar pada pemberian obat. Penelitian ini diharapkan dapat membantu terselenggaranya kegiatan keselamatan pasien khususnya pemeberian obat terkait 7 benar secara efektif untuk mengurangi angka insiden kesalahan pemberian obat di rumah sakit.

\section{METODE}

Penelitian ini merupakan penelitian dengan pendekatan deskriptif cross sectional dengan mempelajari dokumendokumen RS Panti Nirmala tentang Standar Prosedur Operasional (SPO) pemberian obat berdasarkan prinsip 7 benar, form ODD (One Daily Dose) pemberian obat, kuesioner, dan observasi dengan checklist terhadap perawat pelaksana yang berjumlah 39 orang di tujuh unit ruang rawat inap RS Panti Nirmala (RSPN).

Observasi yang dilakukan bertujuan untuk mengamati tingkat ketaatan pelaksanaan SPO penerapan 6 prinsip dari 7 benar pada pemberian obat oleh perawat di ruang rawat inap RS panti Nirmala. Observasi dilakukan pada shift pagi dan sore pada saat waktu pemberian obat, baik obat oral dan intravena. Observasi dilakukan menggunakan checklist pemberian obat, yang terdiri dari benar pasien, benar obat, benar dosis, benar waktu, benar cara dan benar dokumentasi. Untuk prinsip benar indikasi tidak dilakukan observasi dikarenakan, benar indikasi dilakukan oleh apoteker.

Setelah dilakukan observasi, kemudian perawat diberikan kuesioner yang bersifat tertutup untuk mengukur variabel pengetahuan yang terdiri dari 13 item pertanyaan, 11 item pertanyaan untuk variabel sikap dan 2 pertanyaan untuk mengukur variabel kemauan perawat dalam menerapkan 
prinsip 7 benar pada proses pemberian obat di ruang rawat inap RSPN.Selain diberikan pertanyaan tertutup, kuesioner juga berisi pertanyaan terbuka yang terdiri dari 2 item tentang faktor yang menghambat perawat dalam melaksanakan prisnsip 7 benar. Selain itu peneliti melakukan study literatureuntuk membuat instrumen penelitian berupa kuesioner untuk mengukur pengetahuan, sikap dan kemauan perawat dalam pelaksanaan penerapan prinsip 7 benar pada pemberian obat. Kuesioner dibagikan kepada perawat pelaksana di ruang rawat inap RSPN dengan jumlah 49 orang.

Pencarian akar masalah dilakukan dengan diskusi pakar RS. Panti Nirmala, dilanjutkan dengan penggunaan diagram Fishbone, serta menggunakan metode skoring urgency, severity, and growth (USG). Metode USG dilakukan dengan menilai masing-masing masalah berdasarkan tingkat urgensi, keseriusan dan perkembangan masalah apabila tidak dilakukan intervensi dengan menggunakan skala nilai 1-5.

\section{HASIL}

\section{Pelaksanaan Penerapan 6 dari 7 Benar}

Hasil pengamatan terhadap kegiatan perawat pada proses pemberian obat berdasarkan SPO tujuh benar bahwa masih terdapat komponen dari tujuh benar yang masih belum dilakukan sesuai standar prosedur operasional. Pelaksanaan pemberian obat berdasarkan prisnsip tujuh benar di ruang rawat inap RS Panti Nirmala, secara keseluruhan sudah berjalan dengan baik tetapi masih terdapat beberapa indikator yang belum berjalan secara optimal. Observasi pelaksanaan pemberian obat diruang rawat inap dilakukan di tujuh ruangan rawat inap RSPN, proses pengamatan dilakukan pada shift pagi dan sore.

Tabel 1. Hasil observasi ketaatan pelaksanaan SPO penerapan 6 dari 7 benar di ruang rawat inap

\begin{tabular}{lc}
\hline Standar Prosedur Operasional & $\%$ \\
\hline Identifikasi pasien & 64,9 \\
Identifikasi obat & 86,5 \\
Identifikasi dosis & 100 \\
Identisikasi waktu & 64,9 \\
Identifikasi cara & 100 \\
Identifikasi dokumentasi & 100 \\
\hline
\end{tabular}

Berdasarkan observasi di ruang rawat inap, ketaatan petugas dalam menerapkan SPO 7 benar belum dilaksanakan secara optimal.Pengamatan dilakukan terhadap kepatuhan pelaksanaanSPO dalam identifikasi pasien (dalam rangka menentukan Benar Pasien), identifikasi obat (dalam rangka menentukan benar Obat), identifikasi dosis obat (dalam rangka menentukan Benar Dosis), identifikasi waktu pemberian obat (dalam rangka menentukan Benar Waktu pemberian), identifikasi cara pemberian obat (dalam rangka menentukan Benar cara pemberian obat), identifikasi dokumentasi Obat (dalam rangka menentukan Benar Dokumentasi).

Hasil observasi yang dilakukan di ruang rawat inap, penerapan SPO dalam rangka tujuh benar masih ada yang belum dilakukan, 64,9\% perawat melakukan SPO benar identifikasi pasien pada saat pemberian obat, dengan cara perawat membaca gelang nama pasien yang dikenakan oleh pasien dan meminta pasien untuk mengkonfirmasi nama dan alamat atau nama dan tanggal lahir, dan mencocokkannya dengan etiket yang tertera pada obat yang akan diberikan serta lembar obat pasien. Nilai yang kurang dari $100 \%$ pada pelaksanaan SPO tujuh benar menunjukkan bahwa proses yang disyaratkan dalam standar tujuh benar belum dilaksanakan sesuai SPO yang ada, contoh: bila dituliskan bahwa benar pasien sebesar $64,9 \%$ hal ini berarti bahwa perawat tidak melakukan proses identifikasi sesuai dengan standar SPO yang ada, namun bukan berarti bahwa sebanyak $35,1 \%$ salah pasien, demikian pula dengan benar obat dan benar waktu. Hasil observasi identifikasi obat menunjukkan bahwa sebanyak $86,5 \%$ perawat melakukan proses sesuai standar SPO identifikasi obat yaitu membaca nama obat, sediaan, dan expired date obat sebelum obat diberikan pada pasien. Terdapat $64,9 \%$ perawat yang patuh pada pemberian obat sesuai prinsip benar waktu pemberian dengan standar operasional prosedur RSPN. Seluruh perawat melakukan identifikasi benar dosis obat pada saat sebelum obat diberikan yaitu dengan memeriksa jumlah obat yang tertera pada label dan memeriksa kesesuaian dosisnya di catatan pemberian obat. Pada identifikasi benar cara pemberian, seluruh perawat menggunakan prinsip ini sesuai dengan standar operasional prosedur dengan baik yaitu perawat membaca cara pemberian pada label obat yang diberikan, dan juga seluruh perawat melaksanakan dengan baik pada identifikasi benar dokumentasi yaitu perawat mendokumentasikan dosis, rute, waktu dan oleh siapa obat itu diberikan. Secara keseluruhan berdasarkan tujuh komponen pada SPO penerapan tujuh benar pada proses pemberian obat sudah berjalan dengan baik, tetapi masih terdapat beberapa komponen yang masih perlu untuk diperbaiki pelaksanaannya.

Setelah dilakukan observasi, peneliti memberikan kuesioner kepada perawat pelaksana ruang rawat inap RSPN. Pengambilan data tentang pengetahuan, sikap, dan kemauan perawat dilakukan dengan membagikan kuesioner di Instalasi Rawat Inap RSPN. Instrumen penelitian yang digunakan telah dilakukan uji validitas dan reliabilitas dengan menggunakan SPSS yang bertujuan untuk mengukur tingkat kehandalan instrumen. Hasil uji reliabilitas pada variable sikap yaitu dengan nilai 0,870 dan variabel kemauan dengan nilai 0,801 dapat disimpulkan bahwa variabel sikap dan kemauan reliabel untuk dijadikan instrument penelitian, karena nilai hasil cronbach alpha $>0,05$. Responden pada penelitian ini adalah perawat yang bekerja pada instalasi rawat inap dengan minimal bekerja 1 tahun. Kuesioner dibagikan kepada 49 responden tetapi terdapat 3 kuesioner yang tidak termasuk kedalam kriteria responden, sehingga tidak diikutkan dalam analisis, maka jumlah responden pada penelitian ini 46 orang. Jumlah responden ini diharapkan dapat mewakili perawat secara keseluruhan. Berdasarkan data responden yang di dapat, karakteristik responden disajikan pada Tabel 2 . Tabel 2 menunjukkan bahwa dari 46 responden penelitian, sebagian besar (100\%) adalah perempuan berusia 21-30 tahun. Tingkat pendidikan responden mayoritas adalah D3 yaitu sebanyak 95,7\% sisanya berpendidikan sarjana 4,3\%. Mayoritas responden (76\%), bekerja selama kurang lebih 1-5 tahun, dan $67,4 \%$ dari jumlah responden adalah pekerja dengan status kepegawaian tetap. 
Tabel 2. Karakteristik perawat

\begin{tabular}{llcc}
\hline & Karakteristik & Jumlah & Persentase \\
\hline Jenis Kelamin & Laki-laki & 0 & 0 \\
\multirow{3}{*}{ Usia } & Perempuan & 46 & 100 \\
& $21-25$ & 20 & 43,5 \\
& $26-30$ & 21 & 45,6 \\
& $31-35$ & 2 & 4,3 \\
& $36-40$ & 1 & 2,2 \\
Pendidikan & $41-45$ & 1 & 2,2 \\
\multirow{5}{*}{ Pekerjaan } & $46-50$ & 1 & 2,2 \\
& D3 & 44 & 95,7 \\
& S1 & 2 & 4,3 \\
& $1-5$ tahun & 35 & 76 \\
& $6-10$ tahun & 6 & 13 \\
& $11-15$ tahun & 4 & 8,7 \\
& $16-20$ tahun & 0 & 0 \\
& $21-25$ tahun & 1 & 2,3 \\
& Kontrak & 15 & 32,6 \\
& Tetap & 31 & 67,4 \\
\hline
\end{tabular}

Kuesioner yang mengukur tingkat pengetahuan perawat tentang pemberian obat berdasarkan tujuh benar, terdiri dari 13 pertanyaan. Berdasarkan kategori yang dibuat oleh Arikunto yaitu kategori baik jika nilainya $>75 \%$, kategori cukup jika nilainya $<56-74 \%$, dan kategori kurang jika nilainya $<55 \%$ (11). Dari hasil kuesioner yang diterima, didapatkan hasil bahwa terdapat $89 \%$ perawat rawat inap RSPN memiliki pengetahuan yang baik tentang prosedur pemberian obat berdasarkan tujuh benar. Ada sebanyak 5 orang perawat yang memiliki pengetahuan cukup dengan bobot nilai hasil $61,5 \%$.

Hasil kuesioner sikap perawat menunjukkan bahwa responden memiliki sikap yang baik pada pelaksanaan pemberian obat berdasarkan tujuh benar. Hasil kuesioner sikap perawat secara lengkap disajikan pada Tabel 3. Tabel 3 menunjukkan nilai mean dari 11 indikator yang ada mencapai nilai diatas 3,5. Nilai mean tertinggi terdapat pada indikator 7 benar penting dilakukan untuk keselamatan pasien dengan nilai 4,80 dan nilai mean terendah terdapat pada indikator penerapan 7 benar menambah beban kerja dengan nilai 3,56. Nilai mean sebesar 3,56 tersebut menunjukkan bahwa masih ada perawat yang menganggap bahwa penerapan 7 benar menambah beban kerja.

Pemberian obat berdasarkan 7 benar penting untuk dilakukan untuk keselamatan pasien $80,4 \%$ perawat menyatakan sangat setuju, dan $52,2 \%$ perawat sangat setuju bahwa pemberian obat berdasarkan 7 benar membuat pemberian obat menjadi lebih aman. Ada 2,2\% perawat yang menyatakan tidak setuju bahwa pemberian obat yang dilakukan perawat harus berdasarkan SOP, dan $10,9 \%$ perawat merasa setuju dengan pemberian obat berdasarkan 7 benar menambah beban kerja perawat serta $4,3 \%$ perawat menyatakan setuju melakukan prinsip 7 benar dengan terpaksa.

Tabel 3. Deskripsi variabel sikap terhadap pelaksanaan pemberian obat berdasarkan 7 benar

\begin{tabular}{clc}
\hline No & \multicolumn{1}{c}{ Indikator } & Mean \\
\hline $\mathbf{1}$ & $\begin{array}{l}\text { 7 Benar penting dilakukan untuk keselamatan } \\
\text { pasien }\end{array}$ & 4,804 \\
$\mathbf{2}$ & $\begin{array}{l}\text { Pemberian obat yang dilakukan oleh perawat } \\
\text { harus sesuai SOP }\end{array}$ & 4,565 \\
\hline
\end{tabular}

Tabel 3. Deskripsi variabel sikap terhadap pelaksanaan pemberian obat berdasarkan 7 benar (Lanjutan)

\begin{tabular}{clc}
\hline No & \multicolumn{1}{c}{ Indikator } & Mean \\
\hline $\mathbf{3}$ & $\begin{array}{l}\text { Perawat perlu untuk memberi masukan pada } \\
\text { dokter untuk penerapan benar indikasi }\end{array}$ & 3,760 \\
$\mathbf{4}$ & $\begin{array}{l}\text { Penerapan 7 benar menambah beban kerja } \\
\text { (reversed item) }\end{array}$ & 3,565 \\
$\mathbf{5}$ & $\begin{array}{l}\text { Penerapan 7 benar membuat lebih disiplin dalam } \\
\text { pemberian obat }\end{array}$ & 4,456 \\
$\mathbf{6}$ & $\begin{array}{l}\text { Standar 7 benar membuat menjadi lebih konsisten } \\
\text { dan disiplin }\end{array}$ & 4,500 \\
$\mathbf{7}$ & $\begin{array}{l}\text { Perawat harus memastikan obat sudah diminum } \\
\mathbf{8}\end{array}$ & $\begin{array}{l}\text { Medication Error dapat terjadi bila prinsip 7 benar } \\
\text { tidak dilaksanakan }\end{array}$ \\
$\mathbf{9}$ & $\begin{array}{l}\text { Perawat terpaksa dalam melakukan prinsip 7 } \\
\text { benar (reversed item) }\end{array}$ & 4,543 \\
$\mathbf{1 0}$ & $\begin{array}{l}\text { Penerapan 7 benar memudahkan memberikan } \\
\text { obat dengan lebih baik }\end{array}$ & $\mathbf{3 , 8 9 1}$ \\
$\mathbf{1 1}$ & $\begin{array}{l}\text { Penerapan 7 benar membuat pemberian obat } \\
\text { menjadi lebih aman }\end{array}$ & 4,260 \\
\hline
\end{tabular}

Gambaran variabel kemauan, menunjukkan bahwa secara umum perawat mau menjalankan prinsip tujuh benar dalam pemberian obat, dengan nilai mean 4,52. Secara keseluruhan variabel kemauan mempunyai nilai mean diatas 4, namun masih terdapat responden yang menyatakan ragu-ragu sebesar $10,9 \%$ pada kesediaan untuk mengingatkan teman seprofesi ketika prinsip tujuh benar tidak dilakukan dalam pemberian obat.

Tabel 4. Deskripsi variabel kemauan terhadap pelaksanaan pemberian obat berdasarkan 7 benar

\begin{tabular}{llc}
\hline No & \multicolumn{1}{c}{ Indikator } & Mean \\
\hline $\mathbf{1}$ & $\begin{array}{l}\text { Perawat akan menjalankan 7 benar dalam } \\
\text { pemberian obat }\end{array}$ & $\mathbf{4 , 5 2 1}$ \\
$\mathbf{2}$ & $\begin{array}{l}\text { Perawat akan mengingatkan teman seprofesi ketika } \\
\text { prinsip 7 benar tidak dilakukan dalam pemberian } \\
\text { obat }\end{array}$ & $\mathbf{4 , 3 4 7}$ \\
\hline
\end{tabular}

Dari hasil pertanyaan terbuka yang terdapat pada kuesioner didapatkan hasil bahwa dalam melaksanakan prinsip tujuh benar banyak sekali kendala-kendala yang dihadapi perawat, diantaranya persepsi perawat tentang beban kerja yang tinggi, dengan jumlah perawat yang tidak sesuai. Hal tersebut, dapat mengakibatkan perawat melakukan pekerjaan dengan tergesa-gesa. Hal ini mengakibatkan tingkat ketelitian perawat menjadi berkurang. Kesalahan pengobatan bukan hanya ditimbulkan oleh perawat tetapi setiap invidu yang terlibat dapat berpotensi untuk melakukan kesalahan. Tetapi hal ini dikarenakan individu tersebut tidak mengikuti prosedur yang telah ada. Kondisi ketenagaan, manejemen, dan faktor lingkungan dapat menjadikan kendala bagi perawat dalam menerapkan prinsip tujuh benar. Mobilitas yang tinggi bisa membuat perawat tidak menerapkan prinsip tujuh benar, dan faktor eksternal lainnya yang dapat mempengaruhi perawat dalam melakukan prinsip tujuh benar diantaranya adalah supervisi. Ada dampak apabila prinsip tujuh benar tidak diterapkan dengan baik, baik bagi perawat, pasien maupun rumah sakit. Hal ini tentunya tidak sesuai dengan peran perawat yang dalam 
memberikan obat tentunya harus mendukung keefektifan obat. Faktor komunikasi juga dapat menjadi salah satu faktor pengahambat pelaksanaan pemberian obat berdasarkan tujuh benar.

Tabel 5. Jawaban pertanyaan terbuka

\begin{tabular}{|c|c|c|}
\hline SDM & Sistem & Pasien \\
\hline $\begin{array}{l}\text { Keterbatasan } \\
\text { tenaga }\end{array}$ & Tidak ada reward & $\begin{array}{l}\text { Pasien merasa } \\
\text { bosan, dan protes } \\
\text { apabila sering } \\
\text { ditanya }\end{array}$ \\
\hline Kurang disiplin & $\begin{array}{l}\text { Sistem pelayanan } \\
\text { obat di famasi } \\
\text { yang lama }\end{array}$ & $\begin{array}{l}\text { Tingkat pendidikan } \\
\text { keluarga pasien }\end{array}$ \\
\hline $\begin{array}{l}\text { Kurang komunikasi } \\
\text { antar petugas }\end{array}$ & $\begin{array}{l}\text { Dokter visit yang } \\
\text { lama }\end{array}$ & $\begin{array}{l}\text { Kondisi pasien } \\
\text { (emergency) }\end{array}$ \\
\hline $\begin{array}{l}\text { Tidak melakukan } \\
\text { crosscheck }\end{array}$ & $\begin{array}{l}\text { Butuh waktu yang } \\
\text { lama/ efisiensi }\end{array}$ & $\begin{array}{l}\text { Kendala bahasa, } \\
\text { komunikasi dengan } \\
\text { pasien atau keluarga }\end{array}$ \\
\hline \multicolumn{3}{|l|}{$\begin{array}{l}\text { Kurang teliti } \\
\text { Tindakan medis } \\
\text { yang banyak }\end{array}$} \\
\hline $\begin{array}{l}\text { Tim supervisi yang } \\
\text { tidak berjalan }\end{array}$ & & \\
\hline
\end{tabular}

\section{Akar Penyebab Masalah dan Alternatif Solusi}

Pencarian akar masalah dilakukan melalui diskusi pakar, dilanjutkan dengan menggunakan alat bantu diagram fishbone. Berdasarkan hasil diskusi yang dilakukan dengan pakar untuk mencari akar masalah dengan diagram Fishbone Ishikawa (gambar 1) dan metode skoring USG maka ditemukan 3 akar penyebab masalah sebagai berikut: metode pengawasan terhadap perilaku ketaatan perawat belum berjalan optimal, belum adanya sistem reward dan punishment terhadap ketaatan protap, dan komunikasi yang kurang efektif antara perawat dengan pasien.

Proses pemilihan akar masalah dengan diskusi bersama pakardan menggunakan teknik skoringUrgency, Seriousness dan Growthness(USG) pada tabel 5. Berdasarkan metode tersebut terpilih skor masalah yang tertinggi adalah komunikasi yang tidak efektif antara perawat dengan perawat dan juga perawat dengan keluarga. Masalah ini dianggap penting dikarenakan perawat merupakan ujung tombak pelaksana tindakan keperawatan di rumah sakit.

Tabel 6. Tabel metode pemilihan akar masalah dengan USG

\begin{tabular}{clccccc}
\hline No & Masalah & U & S & G & Total & Ranking \\
\hline $\mathbf{1}$ & $\begin{array}{l}\text { Belum ada reward and punishment } \\
\text { terhadap ketaatan pelaksanaan } \\
\text { budaya safety pemberian obat }\end{array}$ & 2 & 1 & 2 & 4 & 3 \\
$\mathbf{2}$ & $\begin{array}{l}\text { Metode pengawasan terhadap } \\
\text { perilaku ketaatan belum optimal } \\
\text { Komunikasi yang tidak efektif } \\
\text { antara perawat dengan perawat } \\
\text { dan juga perawat dengan keluarga }\end{array}$ & 3 & 3 & 2 & 18 & 2 \\
\hline
\end{tabular}

\section{DISKUSI}

Berdasarkan hasil observasi pada kegiatan pemberian obat oleh perawat, bahwa pelaksanaan pemberian obat berdasarkan prisnsip tujuh benar di ruang rawat inap RS Panti Nirmala, secara keseluruhan sudah berjalan dengan baik tetapi masih terdapat beberapa indikator yang belum berjalan secara optimal seperti benar identifikasi, benar obat dan benar waktu yang ditandai dengan nilai tingkat pelaksanaan dibawah dari $100 \%$.

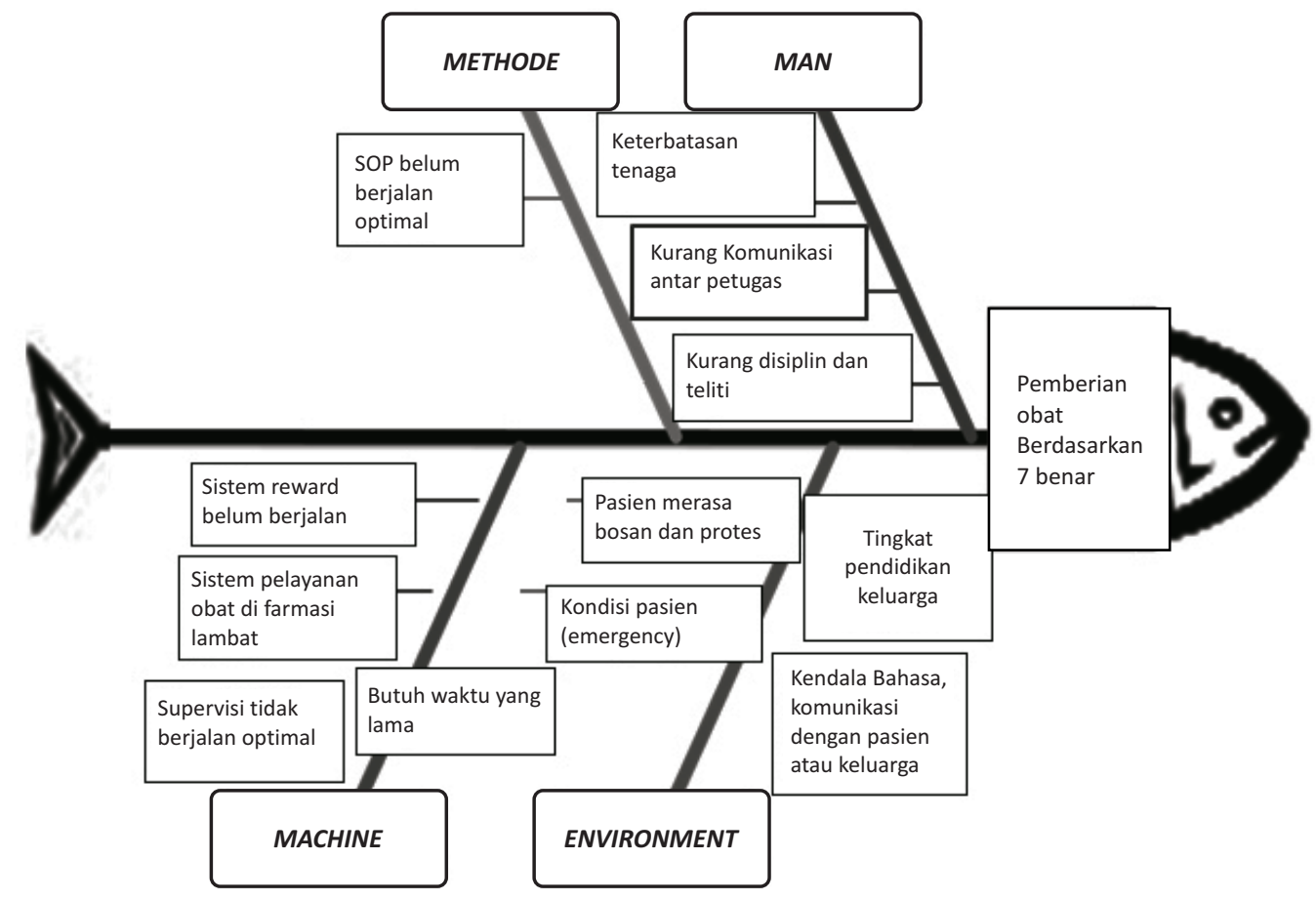

Gambar 1. Diagram Fishbone untuk mencari akar masalah penghambat pelaksanaan tujuh benar pada proses pemberian obat 
Pada variabel pengetahuan perawat, didapatkan hasil bahwa sebagian besar perawat RSPN yaitu sebanyak $89 \%$ memiliki pengetahuan yang baik, tentang pemberian obat berdasarkan prinsip 7 benar. Begitu juga pada variabel sikap dan kemauan perawat, berdasarkan hasil kuesioner menyatakan bahwa perawat RSPN memiliki sikap yang baik dalam pelaksanaan pemberian obat berdasarkan tujuh benar dan mau menjalankan prinsip tujuh benar dalam pemberian obat. Dalam melaksanakan prinsip tujuh benar terdapat beberapa kendala-kendala yang dihadapi perawat, hal tersebut dapat mengakibatkan perawat tidak melakukan prinsip 7 benar dengan baik.

Berdasarkan hasil pertanyaan terbuka dari kuesioner yang diberikan dan fishbone didapatkan 3 area yang menjadi faktor penghambat perawat dalam melaksanakan prinsip 7 benar pada proses pemberian obat di ruang rawat inap RS. Panti Nirmala, yaitu faktor sumber daya manusia (SDM), sistem dan pasien.

\section{Sumber Daya Manusia}

Salah satu akar penyebab masalah adalah persepsi perawat merasa bahwa tenaga kerja yang tidak memadai, dengan beban kerja yang tinggi. Rumah Sakit Panti Nirmala memiliki tenaga kerja perawat sebanyak 232 orang dengan 192 tempat tidur. Berdasarkan shift yang dibagikan, jumlah perawat yang bekerja setiap shift pagi mencapai 6-7 perawat, 5-6 orang perawat bekerja pada shift sore dan 3-4 orang perawat pada shif malam di setiap ruang rawat inap RS. Panti Nirmala. Peraturan Menteri Kesehatan RI No. 340/MENKES/PER/III/2010 tentang Klasifikasi Rumah Sakit, untuk perbandingan antara jumlah tempat tidur RS dibanding dengan jumlah perawat, bahwa rumah sakit kelas C memiliki perbandingan2 perawat: 3 tempat tidur (12). Oleh sebab itu persepsi perawat akan SDM yang kurang memadai tidak terbukti terlihat dari jumlah perawat yang ada dengan jumlah tempat tidur. RS. Panti Nirmala memiliki jumlah perawat yang lebih dari cukup dari jumlah yang seharusnya.

Disiplin perawat sangatlah harus diperhatikan karena merupakan salah satu kunci keberhasilan dalam pelaksanaan pemberian obat berdasarkan 7 benar. Kurang disiplinnya perawat di ruang rawat inap RS. Panti Nirmala menjadi hambatan dalam melaksanakan 7 benar. Akibat kurang disiplinnya perawat, dapat berpotensi menyebabkan kesalahan di dalam pemberian obat. Perawat melakukan pekerjaan dengan tergesa-gesa, tidak melakukan pengecekan kembali, hal ini mengakibatkan tingkat ketelitian perawat menjadi berkurang. Keberhasilan suatu organisasi dalam mencapai suatu tujuan ditentukan dari mutu profesionalitas yaitu disiplin para pegawainya (13). Dengan disiplin kerja yang bagus, setiap perawat akan selaku menjaga pekerjaannya dengan baik dan tidak akan membiarkan pekerjaannya terbengkalai. Dengan penerapan sikap disiplin, maka pelayanan kepada pasien akan aman dan memuaskan.

Berdasarkan metode pengawasan terhadap perilaku ketaatan perawat pada pelaksanan protap belum optimal. Sistem pengawasan kepala ruangan terhadap pelaksanaan prosedur keselamatan pasien dan ketaatan perawat pada pelaksanaan protap pada shift pagi dirasakan cukup. Kepala ruang selalu mengingatkan anggota jika tidak melakukan prosedur pelaksanaan pemberian obat berdasarkan prinsip tujuh benar dengan baik. Kurang optimalnya peran tim mutu yang secara bergantian melaksanakan pengawasan melalui observasi secara langsung dengan terlibat dalam proses perawatan dan dalam pengawasan terhadap pelaksanaan budaya safety pemberian obat. Pada shift sore dan malam fungsi pengawasan ini dirasakan juga kurang, sehingga proses pemberian obat berdasarkan tujuh benar sering tidak dilakukan atau tidak selalu dilakukan dengan benar. Perawat tidak selalu mencatat dan melaporkan adanya perawat yang tidak menjalankan pemberian obat menggunakan prinsip tujuh benar. Masih ada rasa tidak enak (sungkan) melaporkan jika terdapat teman atau petugas lain yang tidak melaksanakan prosedur tujuh benar dengan baik.

Dalam rangka mendukung pelayanan keperawatan yang terstandar, maka fungsi supervisi memegang peranan penting dalam manajemen mutu. Kegiatan supervisi dapat berupa dorongan, bimbingan dan kesempatan untuk pertumbuhan keahlian dan keterampilan perawat. Peran supervisi ini dilaksanakan oleh manajer mulai dari tingkat terendah, menengah sampai atas. Melalui supervisi, SDM keperawatan akan mempertahankan kemampuan dan perilaku dalam melaksanakan asuhan keperawatan sehingga kualitas asuhan yang diterima klien selalu sama pada setiap orang. Secara umum yang dimaksud dengan supervisi adalah melakukan pengamatan secara langsung dan berkala oleh atasan terhadap pekerjaan yang dilaksanakan oleh bawahan untuk kemudian apabila ditemukan masalah,segera diberikan petunjuk atau bantuan yang bersifat langsung guna mengatasinya (14).

Kepala ruangan serta tim mutu harus saling berkoordinasi terhadap fungsi pengawasan atau supervisi demi tercapainya tujuan kegiatan keselamatan pasien Kepala ruangan dapat mengawasi kinerja perawat ruangannya dan tim mutu mengawasi kinerja kepala ruangan dan supervise di ruang rawat inap. Jika tugas pengawasan tersebut dilaksanakan dengan baik maka akan mengurangi insiden keselamatan pasien (15).

\section{Peran Sistem Reward terhadap Ketaatan Selalu Tetap}

Menurut Swanborg dalam Molina salah satu fungsi manajemen adalah memimpin sebagai proses pendelegasian, pengawasan, koordinasi dan pengendalian implementasi rencana organisasi. Fokusnya adalah membimbing dan meningkatkan motivasi dengan upaya yang dilakukan yaitu: membuat sistem penghargaan, memberikan umpan balik positif, mengintegrasikan tujuan organisasi dengan staf/individu, mengurangi ketidakpuasan kerja, mendukung sumber daya (SDM, persediaan dan perlengkapan, program diklat, dan sebagainya). Di RSPN belum ada dukungan yang maksimal terhadap program ketaatan protap atau keselamatan pasien. Untuk lancarnya kegiatan keselamatan pasien dan pelakasanaan protap dengan baik untuk itu diperlukan dukungan anggaran dari manajemen untuk kegiatan: pendidikan dan pelatihan (diklat), pengadaan fasilitas pendukung program, monitoring, evaluasi, laporan dan rapat rutin, juga untuk insentif/tunjangan (reward) untuk perawat yang taat dalam melaksanakan tidakan sesuai prosedur. Organisasi dapat memberikan reward atau bonus kepada perawat yang melaksanakan penerapan prinsip 7 benar secara baik dan disiplin. Olek karena itu setiap perawat merasa semangat untuk melaksanakan prinsip 7 benar sebagai tanggung jawab dan kewajibannya. Pemberian reward disesuaikan dengan kemampuan rumah sakit (17).

Komunikasi yang Tidak Efektif antara Perawat dengan Pasien 
Komunikasi sangat dibutuhkan dalam menunjang keberhasilan kesembuhan pasien, baik secara verbal dan non verbal dengan teknik berkomunikasi yang efektif (18). Komunikasi perawat memiliki kontribusi yang unik terhadap keluarga dan pasien yang sangat berpengaruh terhadap kepuasan pasien (19).

Komunikasi yang tidak efektif antara perawat dengan perawat dan juga perawat dengan keluarga menjadi salah satu akar penyebab masalah dalam penerapan prinsip tujuh benar pada proses pemberian obat (20). Pada umumnya perawat mempunyai sikap positif terhadap penerapan prinsip tujuh benar pada pemberian obat, namun tidak selalu melakukannya dengan baik saat akan melakukan tindakan pemberian obat kepada pasien yang dianggap tindakan keperawatan yang bersifat rutin dengan alasan merasa sudah hafal dengan pasien, sibuk atau tidak sempat serta menghindari kebosanan pasien jika terlalu sering diminta untuk menyebutkan identitasnya sebelum pemberian obat. Perawat merasa tindakan pemberian obat menggunakan prinsip tujuh benar dianggap kurang efektif karena diperlukan waktu yang cukup lama pada pelaksanaanya. Faktor lain yang menyebabkan perawat tidak menerapkan prinsip tujuh benar pada pemberian obat adalah faktor komunikasi. Perawat menganggap pasien merasa bosan apabila perawat harus selalu menanyakan pertanyaan yang sering ditanyakan. Persepsi perawat merasa sia-sia dalam memberikan informasi kepada pasien tentang penjelasan obat yang akan diberikan kepada pasien karena faktor

\section{DAFTAR PUSTAKA}

1. Presiden Republik Indonesia. Undang-Undang Republik Indonesia No. 44 Tahun 2009 tentang Rumah Sakit. Jakarta: Sekretariat Negara RI: 2009.

2. Departemen Kesehatan Republik Indonesia. Panduan Nasional Keselamatan Pasien Rumah Sakit (Patient Safety): Utamakan Keselamatan Pasien. Jakarta: Departemen Kesehatan RI; 2006.

3. Institute of Medicine. To Err is Human: Building a Safer Health System. Washington: National Academy Press; 1999.

4. Boedihartono H. Program Akreditasi Rumah Sakit, Memilih Rumah Sakit. Jakarta: Tempo; 2006; hal. 16

5. Departemen Kesehatan Republik Indonesia. Tanggung Jawab Apoteker terhadap Keselamatan pasien. Jakarta: Departemen Kesehatan RI; 2008.

6. Suharjo JB dan Cahyono B. Membangun Budaya Keselamatan Pasien dalam Praktek Kedokteran. Kanisius: Yogjakarta; 2008.

7. Bates, DW, Cullen, DJ, Laird, N, et al. Incidence of Adverse Drug Events and Potential Adverse Drug Events: Implications for Prevention. The Journal of the American Medical Association. 1995; 274(1): 29-34.

8. Aljadhey H, Alhusan A, Alburikan K, Adam M, Murray MD, and Bates DW. Medication Safety Practices In Hospitals: A National Survey In Saudi Arabia. Saudi Pharmaceutical Journal. 2013; 21(2): 159-164.

9. Ahmadi A. Psikologi Sosial. Jakarta: Rineka Cipta; 2009.

10. Rumah Sakit Panti Nirmala. Laporan Tahunan Rumah tingkat pendidikan, dan bahsa menjadi penghambat penerapan prinsip tujuh benar pada proses pemberian obat.

Hal ini terjadi karena jarang diadakan sosialisasi program melalui pendidikan dan pelatihan yang berkaitan dengan keselamatan pasien dan komunikasi yang efektif antara pasien dengan perawat agar pasien tidak merasa bosan. Sebagian besar perawat menyatakan sudah pernah mendapatkan pelatihan dan sosialisasi yang bersifat tentang keselamatan pasien pada awal masuk menjadi karyawan, namun pemberian obat berdasarkan tujuh benar dan hal teknis berkomunikasi yang baik dan efektif antara perawat dengan pasien belum didapatkan secara khusus.

Prinsip tujuh benar pada pemberian obat masih belum berjalan dengan baik di ruang rawat inap RS Panti Nirmala. Adapun kendala yang dihadapi perawat dalam menerapkan prinsip tujuh benar diantaranya persepsi perawat terhadap SDM yang tidak sesuai, sehingga beban kerja perawat yang tinggi membuat perawat tidak disiplin, peran supervisi yang belum berjalan secara optimal. Faktor sistem yang menjadi kendala perawat dalam melaksanakan prinsip 7 benar yaitu belum berjalannya sistem reward terhadap ketaatan pada pelaksanaan keselamatan pasien, serta faktor lingkungan yang mempengaruhi terjadinya perawat tidak dapat melaksanakan prinsip tujuh benar dengan baik yaitu komunikasi yang tidak efektif antara perawat dengan perawat dan juga perawat dengan keluarga.

\section{Sakit Panti Nirmala. Malang: RSPN; 2013.}

11. Arikunto S. Prosedur Penelitian Suatu Pendekatan Praktek. Jakarta: Rineka Cipta; 1998.

12. Menteri Kesehatan Republik Indonesia. Permenkes Nomor: 340/Menkes/PER/III/2010 tentang Klasifikasi Rumah Sakit. Jakarta: Departemen Kesehatan RI; 2010.

13. Hasibuan M. Manajemen Sumber Daya Manusia. Cetakan Keenam Belas. Jakarta: PT. Bumi Aksara; 2012

14. Mangkuprawiro S. Manajemen Sumber Daya Manusia Strategik. Cetakan Ketiga. Jakarta: Ghalia Indonesia; 2014.

15. Kuntarti. Tingkat Penerapan Prinsip Enam Tepat dalam Pemberian Obat Oleh Perawat di Ruang Rawat Inap. Jurnal Keperawatan Indonesia. 2005; 9(1): 1925.

16. Swanburg RC. Pengantar Kepemimpinan dan Manajemen Keperawatan. Jakarta: EGC; 2005

17. Pittet $D$, Allegranzi B, and Storr J. The WHO Clean Care Is Safer Care Programme: Field-Testing to Enhance Sustainability and Spread of Hand Hygiene Improvements. The Journal of Infection and Public Health. 2008; 1(1): 4-10.

18. Indrawati. Komunikasi untuk Perawat. Jakarta: EGC; 2003

19. Green, Lawrence W, and Kreuter MW. Health Promoting Planning: An Educational and Environmental Aproach. Second Edition. California: Mayfield Publishing Company; 1999. 